\section{Scientific journal}

\section{PHYSICAL AND MATHEMATICAL EDUCATION}

Has been issued since 2013.

Науковий журнал

ФІЗИКО-МАТЕМАТИЧНА ОСВІТА

Видається з 2013.
ISSN 2413-158X (online)

ISSN 2413-1571 (print)

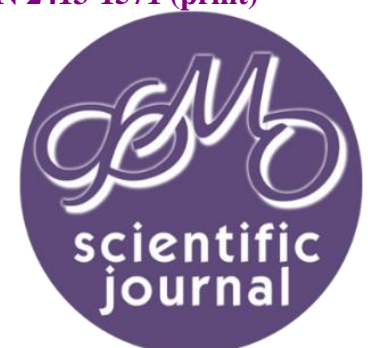

Покришень Д.А. Інформаційна система обліку підвищення кваліфікації освітян у формальній та неформальній освіті. Фізико-математична освіта, 2021. Випуск 5(31). С. 6-10.

Pokryshen D. Information system of accounting for professional development of educators in formal and non-formal education. Physical and Mathematical Education, 2021. Issue 5(31). P. 6-10.

DOI 10.31110/2413-1571-2021-031-5-001

UDC 004.91

D. Pokryshen

Chernihiv Regional Institute of Postgraduate Pedagogical Education. KD Ushinsky, Ukraine pokryshen@ukr.net https://orcid.org/0000-0001-9572-413X

\title{
INFORMATION SYSTEM OF ACCOUNTING FOR PROFESSIONAL DEVELOPMENT OF EDUCATORS IN FORMAL AND NON-FORMAL EDUCATION
}

\section{ABSTRACT}

Formulation of the problem. The article is devoted to the possibility of conducting centralized or regional accounting of professional development of educators, recognition of learning outcomes of various subjects of professional development. The review and analysis of the structure of the information system of accounting for professional development of educators in formal and nonformal education is made, its structural components are characterized. The purpose of its use is determined. An ER model of such a system has been designed. The system of data access and the level of its distribution are determined.

Materials and methods. To achieve this goal, the following research methods were used: theoretical - analysis of legal documents relating to the system of teacher training; generalization of best practices in business documentation, accounting for issued certificates; analysis and systematization of functional responsibilities in educational institutions; diagnostic - research of structure of a database of the account of documents on passing of advanced training for the purpose of necessary structure; analysis of the activities of persons keeping records.

Results. The proposed structure of the information system of accounting for professional development of educators in formal and non-formal education provides for the need to preserve information about the educator, the subject of professional development, acquired competencies and documents received. The structure of each entity is proposed, the indices and the relationship between the components are defined. The information system needs to define users and access rights. Access to the table with information on professional development of educators should be open. This is necessary so that stakeholders and other educators can see how a teacher is involved in professional development. Data entry is provided through authenticated authorized access of the employee responsible for advanced training (internship) and certification. This person has the necessary data about educators, enters this information into the database.

Conclusions. The functioning of such a regional or all-Ukrainian information system for accounting for professional development of educators in formal and non-formal education will address a number of issues arising in the certification and certification of educators.

KEY WORDS: information system, accounting, advanced training, educational trajectory, non-formal education.

\section{INTRODUCTION}

In recent years, there have been many changes in our country. The education sector is no exception. New Laws of Ukraine "On Higher Education", "On Education" have been adopted, and relevant bylaws, such as the resolution of the Cabinet of Ministers of Ukraine approved the "Procedure for professional development of teachers and research and teaching staff." Digitization is being introduced with new force in various state institutions, a new Ministry of Digital Transformation has been created, deputy ministers for digital development are emerging, and so on. The state in the smartphone is slowly becoming a reality. As we see, evolutionary changes are taking place in the ministries, which necessitates the modernization of all systems to ensure the functioning of the branches of these ministries.

The adopted laws for the education sector define new rules for professional development and professional development of pedagogical and scientific-pedagogical workers. This determines the requirements and corresponding changes in these processes for the educators themselves, school administration, departments, ministries.

Now, under the new conditions, there is a loss of monopoly for institutions of postgraduate pedagogical education and educators have the right to decide where, how and when to improve their skills. The subjects of advanced training now include 
public organizations, private entrepreneurs, scientists and experienced teachers. The term, volume, content is determined by the subject of advanced training. Postgraduate pedagogical education institutions or structural subdivisions of higher education institutions that provide postgraduate education must have licenses to conduct such activities. At the same time, subjects related to non-formal education are not required to have such a license, but the documents issued by them require an additional procedure for recognition by the educational institution.

If we talk about secondary and high school teachers, they must in five years receive documents certifying training for at least 150 hours and increased such competencies as professional, innovative, lifelong learning, social and civic, cultural, informational digital, mathematical, in the field of natural sciences, environmental literacy and healthy lifestyle, business and financial, speech, communication in the state language, communication in foreign languages and others.

Thus, we have the liberalization and free formation of their educational trajectory by teachers within the postgraduate formal and non-formal education, but it also raises the problem of accounting for the documents received.

Analysis of recent research and publications. Peculiarities of adult learning are paid to the researches of Burenko V.M. (Burenko, 2005), Gershunsky B.S. (Gershunsky, 1987), Zyazyun I.A., Kolesnikova I.O., Kramushchenko L.V., Krivonos I.F., Lukyanova L.B., Fopel K. (Fopel, 2010) and others. Aspects of continuing and postgraduate education are considered in the works of Bordovska N.V. (Bordovska, 2006), Dave R. (Dave, 1976), Zyazyun I.A., Kolesnikova I.O., Oliynyk V.V., Oliynyk O.O. (Oliynyk, 2002), Rean A. and others. The issue of non-formal education in the system of postgraduate pedagogical education is considered in the work of the authors M. Kyrychenko, O. Prosina and others (Kyrychenko, Prosina, Kravchynska \& Shven, 2020).

Technologies for creating software, information systems are given attention in the works of domestic and foreign researchers: Braude E.J. (Braude, 2004), Voloshinova S.A., Grishko L.V. (Grishko, 2009), Zhaldaka M.I., Kramar Yu. M., Myers G. (Myers, 1980), Penkov A.V., Randy M., Semerikov S.O. (Semerikov, 2009), Sommerville I., Jacobson A. and others.

In order to monitor and self-assess educational institutions the effectiveness of the introduction of innovative digital technologies in the educational process, to determine the stage of digital development of the educational institution MES together with the European Education Fund with the support of the Ministry of Digital Transformation by Fostering the Use of Innovative Educational Technologies), which is specified in the letter of the Ministry of Education and Science №1 / 9-447 dated 07.09.2021.

Introduction and real use of information-analytical systems in the practical daily activities of educational institutions actualizes the state of material and technical base, demonstrates the level of information development in the management system. Thus, digitalization and digital transformation occurs not only on paper but also in real life.

This article is a development of the study, which began in (Pokryshen\&Krepky, 2012; Pokryshen\&Oleksienko, 2019). Issues of design, development and implementation in educational institutions of information-analytical accounting system for recognition of the results of professional development of educators in formal and non-formal education were left out of consideration.

The purpose of this study is to conduct a structural analysis of the information-analytical system of accounting for professional development of educators in formal and non-formal education.

\section{METHODS OF THE RESEARCH}

According to the purpose the following research methods were used:

theoretical - analysis of legal documents related to the system of teacher training; generalization of best practices in business documentation, accounting for issued certificates; analysis and systematization of functional responsibilities in educational institutions;

diagnostic - research of structure of a database of the account of documents on passing of advanced training for the purpose of necessary structure; analysis of the activities of persons keeping records.

\section{RESULTS AND THEIR DISCUSSION}

As already mentioned, according to the current legislation, professional development of educators must take place constantly. In the "Procedure for professional development of pedagogical and scientific-pedagogical workers" (Postanova Kabinetu Ministriv Ukrayiny) it is stated that the forms of professional development are institutional (full-time, part-time, distance), dual and others. Among the types of advanced training are training in the advanced training program, including participation in seminars, workshops, trainings, webinars, workshops, research internships, self-education, etc. Thus, we see that professional development can take place within formal and non-formal education.

In this study, formal education will be understood as passing advanced training in postgraduate pedagogical education institutions or structural units of higher education institutions engaged in advanced training and having the appropriate licenses for such activities and the issuance of documents (certificates, certificates).

Non-formal education will be understood as passing of advanced training in the form of passing of internships, trainings, master classes at various subjects of advanced training.

If everything is clear and unambiguous with the procedure of enrollment in advanced training courses for licensed organizations, then the received documents on non-formal education need additional approval by pedagogical (academic) councils (paragraph 26 (Postanova Kabinetu Ministriv Ukrayiny)). Paragraph 13 (Postanova Kabinetu Ministriv Ukrayiny) specifies the requirements for the content and content of the document on professional development.

Thus, we have the problem of accounting for professional development of pedagogical and scientific-pedagogical workers and relevant documents. The solution of these problems is possible by creating and maintaining an information-analytical system of accounting for advanced training in formal and non-formal education.

The analysis of current normative documents showed that the information-analytical system should contain information about the educator, the subject of advanced training, acquired competencies and received documents. 
Let's analyze each of the entities (tables). The first table Academic contains information about the pedagogical, scientific and pedagogical worker. Similar to scientometric databases, where there is information about scientists, it is necessary to have an identifier for the educator undergoing advanced training. In addition to the ID, you should keep your last name and first name, email. It is not advisable to keep information about the city of residence or place of work, as advanced training does not depend on the administrative division of the territory and the legal name of the educational institution.

The second essence concerns the subject of advanced training. Today, educators have the right to choose where and how to improve their skills (institutions of postgraduate pedagogical education, free educational institutions, public organizations, entrepreneurs, scientists, other educators, in the workplace), so it is advisable to fix these subjects. Therefore, the table Subject of advanced training consists of the following fields identifier, name, official website, information about the license, its image. An official website is needed because it is necessary to publish information about the courses taken by the educator, which is provided by the procedure for professional development. Information about the presence of a license in the subject is necessary, because in its absence, the document and the results of advanced training must be approved by the relevant pedagogical or academic councils where the educator works.

The professional development of an educator is to increase the level of not only hard skills (the subject he teaches) but also other soft skills. Therefore it is necessary to add the table with the list of competences. But take into account the fact that during the year the educator can increase different competencies or simultaneously (multi-hour courses).

The main table should contain the record identifier, information about the educator, subject of advanced training, course topic, date of receipt of the document, number of hours, reference to the document (certificate, certificate, certificate), reference to disclosure of information from the subject and whether approved by pedagogical or scientific council. In the case of courses taken by a licensed entity, the approval mark is set automatically.

The conceptual ER-model of such an information-analytical system is presented in Figure 1.

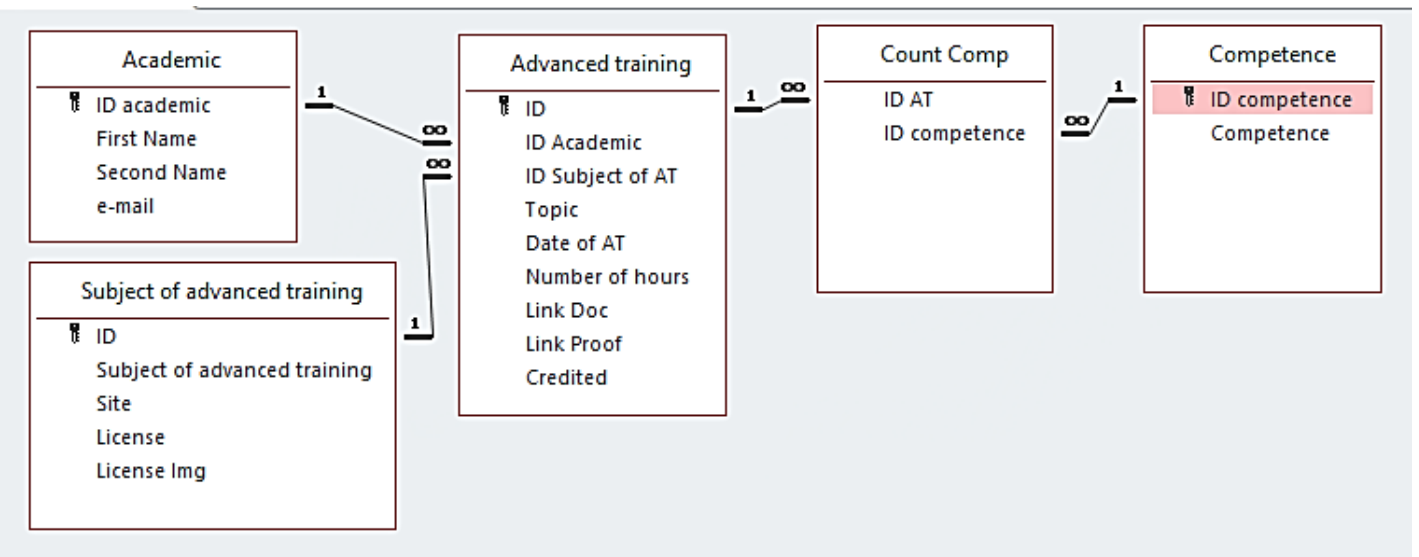

Fig. 1. ER-model of information system of accounting for professional development of educators in formal and non-formal education

Access to the table with information on professional development of educators should be open. This is necessary so that students, parents, the administration of the educational institution, education authorities and other educators can see how this or that educator is engaged in professional development.

The current state of development of desktop (Linux, Windows, MacOS X distributions) and mobile (iOS, Android, Fuchsia, HarmonyOS) operating systems, changing levels of abstraction, the transition to multi-core, the introduction of big.LITTLE in X86 and other technological solutions emphasize the need universal access to this IAS. The solution to this problem is to use a web interface (HTML, CSS, Java, PHP, etc.). Thus, the system will not depend so much on changes in technology and available hardware for users.

The system of queries, reports, sorting and filtering of data in the system will provide the formation of the necessary reporting, analytics, monitoring, ease of use of the system.

The proposed accounting system can be national, where data on all educators will be entered, or local, for use within the educational institution. Note the fact that in the case of implementation of such local systems and confirmation of their convenience and efficiency, the implementation of a common state system will not require much effort and time.

The organization of access for data entry is realized with the help of authenticated authorized access. Each educational institution has an employee who is responsible for advanced training (internship) and certification. It has all the necessary information about educators, their courses, trainings, webinars and information about the time and date of certification. In this case, the effectiveness of maintaining the database, entering data and keeping them up to date depends on the responsibility of teachers and timely informing the administration about the documents received from formal and non-formal education, as well as the employee who has access to the system.

\section{CONCLUSIONS}

The existence and maintenance of such a regional or all-Ukrainian information-analytical system of accounting for professional development of educators in formal and non-formal education will solve a number of issues that arise during the certification and certification of educators. Every head of an educational institution and the educator himself can observe the process of professional growth of teachers, understand the relevance of skills and existing gaps. Students and their parents will be able to choose the best educational institutions and the best teachers for themselves. Thus, the information system of accounting for 
professional development of educators in formal and non-formal education opens up new opportunities for the formation of educational trajectories and prompt information of all stakeholders and the active introduction of digitalization in the management of educational institutions.

\section{References}

1. Bordovskaya, N.V. \& Rean, A.A. (2006) [Pedagogy]. St.Peterbyrg: Piter [in Russian].

2. Braude, E. (2004) Tehnologiya razrabotki programnogo obespecheniia [Software development technology]. St.Peterbyrg: Piter [in Russian].

3. Burenko, V.M. (2005) Andrahohichnyy pidkhid do profesiynoyi perepidhotovky vchytelya humanitarnoho profilyu [Andragogic approach to professional retraining of a teacher of humanitarian profile]. Extended abstract of candidate's thesis. Kyiv: Central Institute of Postgraduate Pedagogical Education of the Academy of Pedagogical Sciences of Ukraine [in Ukraine].

4. Dave, R. H. (1976) Foundation of Lifelong Education: Some Methodological Aspects. Hamburg. [in English].

5. Fopel, K. (2010) Psikhologicheskiye printsipy obucheniya vzroslykh [Psychological principles of adult learning]. Moscow: Genesis [in Russian].

6. Gershunsky, B.S. (1987) Komp'yuterizatsiya v sfere obrazovaniya : Problemy i perspektivy [Computerization in the field of education: Problems and prospects]. Moscow: Pedagogica [in Russian].

7. Grishko, L.V. (2009) Metodychna systema navchannya osnov prohramuvannya maybutnikh inzheneriv-prohramistiv [Methodical system of training of bases of programming of future engineers-programmers]. Candidate's thesis. Kyiv: Cherkasy National University named after Bohdan Khmelnytsky [in Ukraine].

8. Myers, G. (1980) Nadozhnost' programmnogo obespecheniya [Reliability of software]. Moscow: Mir [in Russian].

9. Kyrychenko, M., Prosina, O., Kravchynska, T. \& Shven, Ya. (2020) The adult education in nonlinear world: non-formal education in the system of postgraduate education of the Ukrainian Open University. - I Conference on professional development of specialists in the digitized society: current trends (PDSDig-2020), 59-65. [in Ukraine].

10. Oliynyk, O.O. (2002) Pislyadyplomna pedahohichna osvita v Ukrayini v konteksti svitovoho rozvytku [Postgraduate pedagogical education in Ukraine in the context of world development] Postgraduate education in Ukraine, 12. 25-29. [in Ukraine].

11. Oliynyk, V.V. Osvita vprodovzh zhyttya: yak i chomu vchyty doroslykh? [Lifelong learning: how and why to teach adults?]. Retrieved from http://www.apsu.org.ua/ua/info rmation/press/956784/ [in Ukraine].

12. Pokryshen, D.A. \& Krepky, Yu.O. (2012) Funktsional'nyy i strukturnyy analiz informatsiynoyi systemy obliku naukovopedahohichnykh pratsivnykiv [Functional and structural analysis of the information system of accounting of scientific and pedagogical workers] - Information technologies and teaching aids: electronic scientific professional publication. 2 (28) [in Ukraine].

13. Pokryshen, D.A \& Oleksienko, S.O. (2019) Rol' i mistse informatsiyno-analitychnykh system u pidvyshchenni kvalifikatsiyi vchyteliv informatyky [The role and place of information-analytical systems in professional development of computer science teachers] Open educational e-environment of modern University. 6, 55-62. [in Ukraine].

14. Postanova Kabinetu Ministriv Ukrayiny «Deyaki pytannya pidvyshchennya kvalifikatsiyi pedahohichnykh i naukovopedahohichnykh pratsivnykiv»[Resolution of the Cabinet of Ministers of Ukraine "Some issues of professional development of pedagogical and scientific-pedagogical workers"]. zakon.rada.gov.ua. Retrieved from https://zakon.rada.gov.ua/laws/show/ 800-2019-\% D0\% BF \# n10. [in Ukraine].

15. Semerikov, S.O. (2009) Teoretyko-metodychni osnovy fundamentalizatsiyi navchannya informatychnykh dystsyplin u vyshchykh navchal'nykh zakladakh [Theoretical and methodical bases of fundamentalization of training of computer science disciplines in higher educational establishments]. Doctor's thesis. Kyiv: NPU named after Drogomanov. [in Ukraine]

16. Tkachuk, V. O., Yechkalo, Yu., Semerikov, S. O., Kislova, M. \& Khotskina, V. (2020) Exploring Student Uses of Mobile Technologies in University Classrooms: Audience Response Systems and Development of Multimedia: ICT-based Competence Approach. CEUR Workshop Proceedings. 2732 [in English].

17. Shven, Ya. \& Farukhshyna, M. (2020) The Challenge Soft Skills for pedagogical teachers: theoretical analysis and integration in the space of formal and non-formal education. I CONFERENCE ON PROFESSIONAL DEVELOPMENT OF SPECIALISTS IN THE DIGITIZED SOCIETY: CURRENT TRENDS (PDSDig-2020). 251-255. [in English]

\section{ІНФОРМАЦІЙНА СИСТЕМА ОБЛІКУ ПІДВИЩЕННЯ КВАЛІФІКАЦІЇ ОСВІТЯН У ФОРМАЛЬНІЙ ТА НЕФОРМАЛЬНІЙ ОСВІТІ Д.А. Покришень}

Чернігівський обласний інститут післядипломної педагогічної освіти імені К.Д. Ушинського, Україна

\section{Анотація.}

Формулювання проблеми. Стаття присвячена питанням можливості ведення централізованого або регіонального обліку підвищення кваліфікації працівників освіти, визнанням результатів навчання у різних суб'єктів підвищення кваліфікації. зроблено огляд та аналіз структури інформаційної системи обліку підвищення кваліфікації освітян у формальній та неформальній освіті, охарактеризовано їі структурні компоненти. Визначено мету їі використання. Спроектовано ER-модель такої системи. Визначено систему доступу до даних та рівень ї̈ розповсюдження.

Матеріали і методи. Для досягнення поставленої мети було використано такі методи дослідження: теоретичні-аналіз нормативноправових документів, що стосуються системи підвищення кваліфікації учителів; узагальнення передового досвіду з ведення ділової документації, обліку виданих сертифікатів; аналіз та систематизація функціональних обов'язків у закладах освіти; діагностичні - дослідження структури бази даних обліку документів про проходження підвищення квалірікації з метою необхідної структури; проведення аналізу діяльності осіб, що ведуть облікову документацію.

Результати. Запропонована структура інформаційної системи обліку підвищення кваліфікації освітян у формальній та несормальній освіті передбачає необхідність збереження відомостей про освітянина, суб'єкта підвищення квалірікації, здобуті компетентності та отримані документи. Запропоновано структуру кожної сутності, визначено індекси та взаємозв'язок 
між компонентами. Інформаційна система потребує визначення користувачів та прав доступу. Доступ до таблиці із відомостями про підвищення кваліфікації освітян повинен бути відкритим. Це потрібно для того, щоб зацікавлені особи та інші освітяни бачили як той чи інший педагог займається професійним розвитком. Введення даних забезпечується через аутентифікований авторизований доступ працівника, що відповідає за підвищення кваліфікації (стажування) та атестацію. Ця людина має необхідні дані про освітян, вносить ці відомості до бази даних.

Висновки. Функціонування такої регіональної або всеукраїнської інформаційної системи обліку підвищення кваліфікації освітян у формальній та неформальній освіті дозволить вирішити низку питань, що виникають при атестації та сертифікації працівників освіти.

Ключові слова: інформачійна система, облік, підвищення кваліфікації, освітня траєкторія, неформальна освіта.

\section{(cC) EY-NC-SA}

This work is licensed under Creative Commons Attribution-NonCommercial-ShareAlike 4.0 International License. 